\title{
PERSEPSI MASYARAKAT BATAK TOBA TENTANG PENDIDIKAN SEKS BAGI REMAJA DI LINGKUNGAN PARPAREAN III KELURAHAN PARPAREAN III KECAMATAN PORSEA KABUPATEN TOBA TAHUN 2020
}

\author{
Munarni \\ Program Studi D-III Keperawatan, STIKes Arjuna \\ E-mail : arnysweet84@gmail.com
}

\begin{abstract}
Abtract
Sex education is a clear and correct information regarding the issue of human sexuality, which includes the occurrence of conception, pregnancy, sexual behavior, sexual relations and health, psychological and social aspects. The issue of sexual education provided should be related to the norms prevailing in society, what is prohibited, what is legal and how to do it without violating the rules that apply in society. This study aims to determine the perception of the Batak Toba community about sex education for adolescents in the Parparean III environment, Parparean III Village. This research is descriptive using primary data obtained through a questionnaire. The sample in this study was the Batak Toba people who had teenagers who were obtained using a total sampling technique. From the results of this study obtained data, respondents who have positive perceptions as many as 43 people $(81.1 \%)$ and negative 10 people (18.9\%). Given the importance of sex education for adolescents, it is necessary to coordinate between the government, health workers and the community to unifying perceptions about sex education so that adolescents get clear and correct information about sexuality to improve their reproductive health.
\end{abstract}

Keywords : Perception, Toba batak society, Sex education for youth

\begin{abstract}
Abstrak
Pendidikan seks adalah suatu informasi mengenai persoalan seksualitas manusia yang jelas dan benar, yang meliputi terjadinya pembuahan, kehamilan, tingkah laku seksual, hubungan seksual dan aspek-aspek kesehatan, kejiwaaan dan kemasyarakatan. Masalah pendidikan seksual yang diberikan sepatutnya berkaitan dengan norma-norma yang berlaku di masyarakat, apa yang dilarang, apa yang dilazimkan dan bagaimana melakukannya tanpa melanggar aturan-aturan yang berlaku di masyarakat. Penelitian ini bertujan untuk mengetahui persepsi masyarakat Batak Toba tentang pendidikan seks bagi remaja di Lingkungan Parparean III Kelurahan Parparean III. Penelitian ini bersifat deskriptif dengan menggunakan data primer yang didapat melalui kuesioner. Sampel dalam penelitian ini adalah masyarakat Batak Toba yang memiliki remaja yang didapat menggunakan teknik total sampling. Dari hasil penelitian ini didapat data, responden yang memiliki persepsi positif sebanyak 43 orang $(81,1 \%)$ dan negatif 10 orang $(18,9 \%)$.Mengingat pentingnya pendidikan seks bagi remaja, perlu adanya koordinasi antara pemerintah, tenaga kesehatan dan masyarakat untuk menyatukan persepsi mengenai pendidikan seks agar remaja mendapatkan informasi yang jelas dan benar mengenai seksualitas untuk meningkatan kesehatan reproduksinya.
\end{abstract}

Kata kunci : Persepsi, Masyarakat batak toba, Pendidikan seks bagi Remaja 


\section{PENDAHULUAN}

Pendidikan Seks adalah suatu informasi mengenai persoalan seksualitas manusia yang jelas dan benar, yang meliputi proses terjadinya pembuahan, kehamilan sampai kelahiran, tingkah laku seksual, hubungan seksual, dan aspek-aspek kesehatan, kejiwaan dan kemasyarakatan. Masalah pendidikan seksual yang diberikan sepatutnya berkaitan dengan norma-norma yang berlaku di masyarakat, apa yang dilarang, apa yang dilazimkan dan bagaimana melakukannya tanpa melanggar aturan-aturan yang berlaku di masyarakat.

Pendidikan seksual yang baik harus dilengkapi dengan pendidikan etika, pendidikan tentang hubungan antar sesama manusia baik dalam hubungan keluarga maupun di masyarakat. Tujuan dari pendidikan seksual bukan untuk menimbulkan rasa ingin tahu dan rasa ingin mencoba hubungan seksual antar remaja, tetapi ingin menyiapkan agar remaja tahu tentang seksualitas dan akibat-akibatnya bila dilakukan tanpa mematuhi aturan hukum, agama dan adat istiadat serta kesiapan mental dan material seseorang.

Survei oleh WHO tentang pendidikan seks membuktikan, pendidikan seks bisa mengurangi atau mencegah perilaku hubungan seks sembarangan yang berarti pula mengurangi tertularnya penyakit akibat hubungan seks bebas. Pendidikan seks yang benar harus memasukkan unsur-unsur hak azazi manusia, juga nilai-nilai kultur dan agama diikutsertakan di dalamnya sehingga akan merupakan pendidikan akhlak dan moral juga.

Perbedaan dalam menyikapi seks tersebutlah yang mengakibatkan sampai sekarang masih terjadi pro-kontra terhadap perlu tidaknya memberikan pendidikan seks bagi remaja. Kelompok yang menolak beranggapan bahwa pendidikan seks akan menjerumuskan para remaja untuk melakukan hubungan seksual sebelum menikah sementara kelompok yang mendukung beranggapan bahwa pendidikan seks bisa mencegah remaja melakukan hubungan seks sebelum menikah karena telah mengetahui resiko-resiko yang akan dihadapinya.

Berdasarkan penjelasan diatas peneliti merasa tertarik untuk melakukan penelitian untuk mengetahui bagaimana persepsi masyarakat khususnya budaya batak Toba tentang pendidikan seks terhadap remaja di Lingkungan Parparean III Kelurahan Parparean III tahun 2020.

\section{METODE PENELITIAN}

Desain penelitian yang digunakan pada penelitian adalah deskriptif dan bertujuan untuk mengetahui persepsi masyarakat batak Toba tentang pendidikan seks bagi remaja. Penelitian ini dilakukan di kelurahan Parparean III dengan pertimbangan bahwa dikelurahan ini belum pernah dilakukan penelitian mengenai Persepsi masyarakat batak Toba tentang pendidikan seks bagi remaja dan populasi masyarakat yang bersuku batak Toba cukup untuk memenuhi target populasi. Penelitian ini dilakukan mulai bulan Oktober 2020 sampai Desember 2020.

Populasi dalam penelitian ini adalah masyarakat yang bersuku batak Toba di Lingkungan Parparean III kelurahan Parparean III yang memiliki remaja yaitu sebanyak 53 orang. Sampel dalam penelitian ini diambil dengan menggunakan metode total sampling dimana semua populasi dijadikan sampel yaitu masyarakat batak Toba yang berada di Lingkungan Parparean III Kelurahan Parparean III.

Pengumpulan data dilakukan dengan menyebarkan kuisioner pada responden satu persatu dan menjelaskan tujuan penelitian kepada responden. Peneliti kemudian meminta kesediaan responden untuk menjadi responden penelitian dan menandatangani surat persetujuan menjadi responden. Setelah diberi penjelasan mengenai cara pengisian kuisioner, responden diberi waktu untuk mengisi kuisioner sesuai dengan keadaan sebenarnya secara jujur. Kuisioner yang telah terkumpul kemudian diolah dan dianalisis secara statistik (Arikunto. 2009). 


\section{HASIL PENELITIAN}

Hasil dari penelitian ini digambarkan dalam dua bagian yaitu data karakteristik responden dan data mengenai Persepsi Masyarakat Batak Toba tentang Pendidikan Seks bagi Remaja.

\section{Karakteristik Responden}

Berdasarkan hasil penelitian yang terdapat pada table 5.1 mayoritas umur responden berada pada rentang umur 41-50 tahun yaitu 32 orang $(60,4 \%)$. Pendidikan responden mayoritas tamatan SMA yaitu 27 orang $(50,9 \%)$. Pekerjaan responden mayoritas PNS yaitu 22 orang $(41,5 \%)$. Dan mayoritas responden beragama Islam yaitu 53 orang $(100 \%)$. Adapun gambaran data karakteristik responden pada penelitian ini dapat dilihat dari tabel 1 yaitu :

\begin{tabular}{clcc}
\hline No & $\begin{array}{l}\text { Karakteristik } \\
\text { Responden }\end{array}$ & N & \% \\
\hline 1 & Umur & & \\
& 30-40 tahun & 5 & 9.4 \\
& $41-50$ tahun & 32 & 60.4 \\
& $51-60$ tahun & 13 & 24.5 \\
& 61-70 tahun & 3 & 5.7 \\
\hline 2 & Pendidikan & & \\
& SD & 9 & 17.0 \\
& SMP & 27 & 50.9 \\
& SMA & 17 & 32.1 \\
& PT & & \\
\hline 3 & Pekerjaan Responden & & \\
& PNS & 22 & 41.5 \\
& Pegawai Swasta & 8 & 15.1 \\
& Wiraswasta & 7 & 13.2 \\
& Tidak bekerja & 16 & 30.2 \\
\hline 4 & Agama & & \\
& Islam & 53 & 100 \\
\hline & & & \\
& & &
\end{tabular}

\section{Persepsi Masyarakat Batak Toba tentang Pendidikan Seks bagi Remaja}

Dari 53 responden yang diteliti diketahui bahwa persepsi masyarakat batak Toba tentang pendidikan seks bagi remaja adalah mayoritas masyarakat berpersepsi positif sebanyak 43 orang $(81,1 \%)$ dan negatif sebanyak 10 orang $(18,9 \%)$. Adapun gambaran data persepsi masyarakat batak toba dapat dilihat dari tabel 2 yaitu :

\begin{tabular}{clcc}
\hline No & Persepsi & N & \% \\
\hline 1 & Positif & 43 & 81.1 \\
2 & Negatif & 10 & 18.9 \\
\hline & Total & 53 & 100 \\
\hline
\end{tabular}

\section{PEMBAHASAN}

Dari hasil penelitian ini dapat dilihat bahwa persepsi masyarakat batak Toba terhadap pendidikan seks bagi remaja sebagian besar adalah positif yaitu sebanyak 43 orang $(81,1 \%)$ dari total 53 responden. Namun demikian masih ada masyarakat yang berpersepsi negatif yaitu sebanyak 10 orang $(18,9 \%)$. Adanya perbedaan dalam persepsi masyarakat terhadap pendidikan seks bagi remaja tersebut menjelaskan teori yang dikemukakan oleh Siagian (2004) yang menyatakan bahwa persepsi seseorang belum tentu sama dengan fakta yang sebenarnya, untuk itulah mengapa dua orang atau lebih memiliki persepsi yang berbeda terhadap objek yang dipersepsinya.

Objek yang dipersepsi dalam penelitian ini adalah pendidikan seks bagi remaja. Masyarakat batak Toba yang menjadi responden dalam penelitian ini diberi rangsang untuk mempersepsi objek tersebut menyatakan persepsinya dalam bentuk positif maupun negatif. Persepsi dapat menjadi positif apabila masyarakat tersebut menanggapi sesuai dengan penghayatannya dan dapat diterimanya secara rasional dan emosional. Sebaliknya, apabila masyarakat menanggapinya tidak sesuai dengan penghayatannya maka persepsi yang timbul adalah negatif. Keduanya tergantung dari faktor yang mempengaruhi timbulnya persepsi antara lain, dari diri orang yang bersangkutan seperti pengalaman, sikap dan perhatian, maupun faktor luar seperti situasi dan latar belakang agama dan budaya masyarakat dalam hal ini masyarakat batak Toba tersebut.

Hal ini juga menjelaskan mengapa saat diberikan pernyataan-pernyataan mengenai pendidikan seks bagi remaja yang dijabarkan dalam defenisi, tujuan, ruang lingkup materi dan kiat serta bimbingan dalam memberikan pendidikan seks bagi remaja, masyarakat batak Toba yang mejadi 
responden mengartikannya secara berbeda. Hasil penelitian menunjukan masyarakat yang persepsinya positif terhadap defenisi pendidikan seks bagi remaja adalah sebanyak 53 orang (100\%) yaitu semua responden pada penelitian ini berpersepsi positif terhadap defenisi pendidikan seks. Hal ini dikarenakan masyarakat sudah mengetahui pentingnya diberikan pendidikan seks bagi remajanya. Persepsi negatif yang selama ini terdapat di masyarakat yang menganggap pendidikan seks bagi remaja sebagai pendidikan mengenai cara berhubungan seks semata tidak boleh diberikan karena akan membuat remaja semakin ingin melakukan seks, tidak selamanya benar. Masyarakat khususnya responden pada penelitian ini telah mengetahui pentingnya pendidikan seks bagi remaja mereka.

Demikian juga terhadap tujuan pendidikan seks, responden pada penelitian ini berpersepsi positif sebanyak 53 orang $(100 \%)$. Ini artinya masyarakat yang memiliki remaja mengetahui tujuan dari pendidikan seks itu sendiri adalah untuk memberi pengetahuan yang benar mengenai seks sehingga remaja mereka terhindar dari keinginan melakukan hubungan seks yang terlarang karena mengetahui resiko yang akan dihadapinya (Sarwono, 2003).

Dalam hal materi yang diberikan dalam pendidikan seks bagi remaja, responden yang berpersepsi positif sebanyak 51 orang $(96,2 \%)$ dan yang berpersepsi negatif sebanyak 2 orang $(3,8 \%)$. Dalam hal ini juga dapat disimpulkan bahwa masyarakat merespon positif terhadap materi yang diberikan pada pendidikan seks bagi remaja. Sebagian kecil responden pada penelitian ini masih berpersepsi negatif sebanyak 2 orang $(3,8 \%)$ ini mungkin mereka masih mengartikan bahwa materi yang diberikan dalam pendidikan seks hanya mengenai seks saja, padahal materi pendidikan seks jauh lebih luas yang mencakup segala aspek kehidupan manusia.

Demikian juga dalam hal kiat dan bimbingan dalam memberikan pendidikan seks bagi remaja, responden berpersepsi positif sebanyak 53 orang (100\%). Dapat diartikan bahwa masyarakat khususnya masyarakat batak Toba yang menjadi responden dalam penelitian ini sudah mengetahui dengan baik dan benar kiat mereka dalam memberikan bimbingan pendidikan seks bagi remajanya.

Dari hal-hal tersebut diatas dapat dilihat bahwa persepsi masyarakat batak Toba itu sendiri tentang pendidikan seks bagi remajanya adalah persepsi positif sebanyak 43 orang $(81,1 \%)$ dan persepsi negatif sebanyak 10 orang (18,9\%). Peneliti mengasumsikan bahwa masih ada sebagian masyarakat batak Toba yang menganggap pendidikan seks adalah hal yang tabu untuk dibicarakan dan dilarang oleh agama, kemungkinan mereka masih dipengaruhi oleh nilai budaya batak Toba itu sendiri yang men"tabu" kan seks. Selain itu masyarakat menganggap pendidikan seks bukanlah tanggung jawab utama mereka sehingga mereka tidak perlu memahami seksualitas dan kehidupan remaja.

Melihat masih adanya perbedaan dalam persepsi pendidikan seks bagi remaja, peneliti merasa bahwa perlu adanya penyuluhan dan konseling bagi masyarakat agar lebih memahami dan dapat memberikan pendidikan seks bagi remajanya dimulai dari keluarga itu sendiri. Semuanya itu bertujuan agar remaja terhindar dari perilaku seksual yang tidak sehat dan merugikan masa depannya.

\section{KESIMPULAN}

Dari penelitian yang dilakukan terhadap 53 responden yaitu orang tua yang memiliki remaja usia 10-19 tahun di Lingkungan Parparean III Kelurahan Parparean III dapat diambil kesimpulan sebagai berikut:

1. Mayoritas umur responden berada pada rentang umur 41-50 tahun yaitu 32 orang $(60,4 \%)$. Pendidikan responden mayoritas tamatan SMA yaitu 27 orang (50,9\%). Pekerjaan responden mayoritas PNS yaitu 22 orang $(41,5 \%)$. Dan mayoritas responden beragama islam yaitu 53 orang $(100 \%)$ 
2. Mayoritas responden berpersepsi positif tentang pendidikan seks bagi remaja yaitu sebanyak 43 orang $(81,1 \%)$ dan berpersepsi negatif sebanyak 10 orang $(18,9 \%)$

\section{SARAN}

1. Bagi Peneliti

Bagi peneliti agar penelitian ini dikembangkan di Kelurahan Parparean III untuk mengetahui persepsi masyarakat tidak hanya masyarakat batak Toba terhadap pendidikan seks bagi remaja. Selain itu peneliti juga menyarankan agar pada penelitian selanjutnya diteliti secara spesifik faktor-faktor yang mempengaruhi persepsi masyarakat tentang pendidikan seks terhadap remaja.

2. Bagi Profesi keperawatan

Pada penelitian ini masih didapati bahwa ada masyarakat yang berpersepsi negatif tentang pendidikan seks bagi remaja. Hal ini apabila dibiarkan akan membuat remaja tetap tidak mendapatkan informasi yang benar tentang seksualitas. Untuk itu diharapkan agar bidan sebagai pelaksana pelayanan kesehatan reproduksi remaja agar lebih aktif mengadakan penyuluhan dan program pendidikan tentang kesehatan reproduksi bagi remaja dan orang tua.

3. Bagi Responden

Bagi responden agar dapat lebih memahami pentingnya pendidikan seks bagi remajanya.

\section{REFERENSI}

Arikunto. S. (2009). Metode Penelitian, Suatu Pendekatan Praktek. Jakarta : Rineka Cipta

Notoadmodjo. S. (2002). Metodologi Penelitian Kesehatan. Jakarta : Rineka Cipta.

Pratiwi. (2004). Pendidikan Seks Untuk Remaja. Jakarta : Tugu Publisher.

Reiss. M, Halstead, J.M. (2004). Sex Education. From Principles To Practice. Yogyakarta: Alenia Press.

Sarwono, S.W. (2003). Psikologi Remaja. Jakarta : PT. Raja Grafindo Persada.
Siagian. S. (2004). Teori Motivasi dan Aplikasinya. Jakarta : Rineka Cipta.

Suarta. (2002). Pendidikan Seksual dan Reproduksi Berbasis Sekolah??.

Dalam http://situs.kesrepro.info/krr/nov/20 0/krr03.htm. Dibuka tanggal 10 November 2020

Walgito. B. (2002). Pengantar Psikologi Umum. Yogyakarta : Andi Offset.

Wilopo. S.A. (2004). Perlu Layanan Konseling Seks Bagi Remaja. Dalam http://www.suarakaryaonline.com/news.html?id=93686.

Dibuka tanggal 20 Oktober 2020 